\title{
SITUATION OF ENGINEERING GEOLOGY
}

SITUATION DE L'ART DE LA GÉOLOGIE À L'INGÉNIEUR

T. ONODERA

JAPAN

Saitama University, School of Science and Engineering,

Department of Geotechnology, Urawa

\section{SUMMARY :}

Engineering geology is a field of engineering sciences that link pure sciences and engineering as engineering furnishes technical basis for practical human livings. Engineering geology has its foundations on geology and on mechanics, or in unified expression on physico-mechanical approach to geology and geological materials.

In attempting to select materials for teaching and training in engineering geology, most essential point is to recognize the situation of engineering geology as an engineering science among the pure natural sciences, engineering and practical social livings. Considerations on its situation and an example of undergraduate curriculum are presented in this paper.

\section{SOMMAIRE:}

L'art de la Géologie à l'ingénieur est un domaine des sciences de l'ingénieur qui joint les sciences pures à l'art de l'ingénieur comme 1 'art de 1 'ingénieur fournit les bases techniques à la vie humaine pratique.

L'art de la Géologie à l'ingénieur a ses racines en géologie et en mécanique, ou suivant l'expression concentrée dans 1'approche physicomécanique de la géologie et des matériaue pour l'enseignement et la formation dans l'art de la geologie a l'ingenieux, le point le plus essentiel est de reconnaitre la situation de l'art de la Géologie à l'ingénieur comme une science de l'ingénieur parmi les sciences nature1les pures, l'art de l'ingénieur et la vie sociale pratique.

Les considérations sur cette situation et un exemple de curriculum d'étudiant sont présentés dans ce document.

1. Situation of natural science and engineering in relation to social living.

Human living is related to each division of pure sciences -humanities, social sciences and natural sciences- at its very basis. Pure sciences are the liberal arts to study for study following their own interests. However, it is undeniable that they lie as bases of social living through general sequence shown in Table 1 . 
Table 1 Interrelation of pure sciences and social living

\begin{tabular}{|c|c|c|c|c|c|}
\hline $\begin{array}{l}\text { 1iberal } \\
\text { arts }\end{array}$ & application & of sciences & $\begin{array}{l}\text { scientific } \\
\text { founding } \\
\text { for technics }\end{array}$ & $\begin{array}{l}\text { support } \\
\text { for social } \\
\text { action }\end{array}$ & $\begin{array}{l}\text { social } \\
\text { living }\end{array}$ \\
\hline $\begin{array}{l}\text { (human- } \\
\text { ities) }\end{array}$ & techno & logy & $\ldots$ & & $\int^{\text {works }}$ \\
\hline $\begin{array}{l}\text { natural } \\
\text { sciences }\end{array}$ & - applied & $\begin{array}{l}\text { engineering } \\
\text { sciences }\end{array}$ & _ engineering & $g$ - technics - & $\begin{array}{l}\text { indus- } \\
\text { tries }\end{array}$ \\
\hline $\begin{array}{l}\text { (social } \\
\text { sciences) }\end{array}$ & & & & & $\begin{array}{l}\text { busi- } \\
\text { ness }\end{array}$ \\
\hline
\end{tabular}

2. Geology in relation to other natural sciences.

There are two modes of science to research into nature, the one being classic physical (science of energy) and the other being classic chemical (science of material). Besides these modes of research, natural sciences have branches of their own interests as shown in Table 2.

Geology had mainly followed the material science mode in its developing course and the energy science mode had been rather scanty which has had an important bearing upon linking with engineering on and/or in the earth's crust. Soil- and rock-mechanics, geomechanics and main part of structural geology are to fill up this field.

Table 2 Geology in relation to other natural sciences

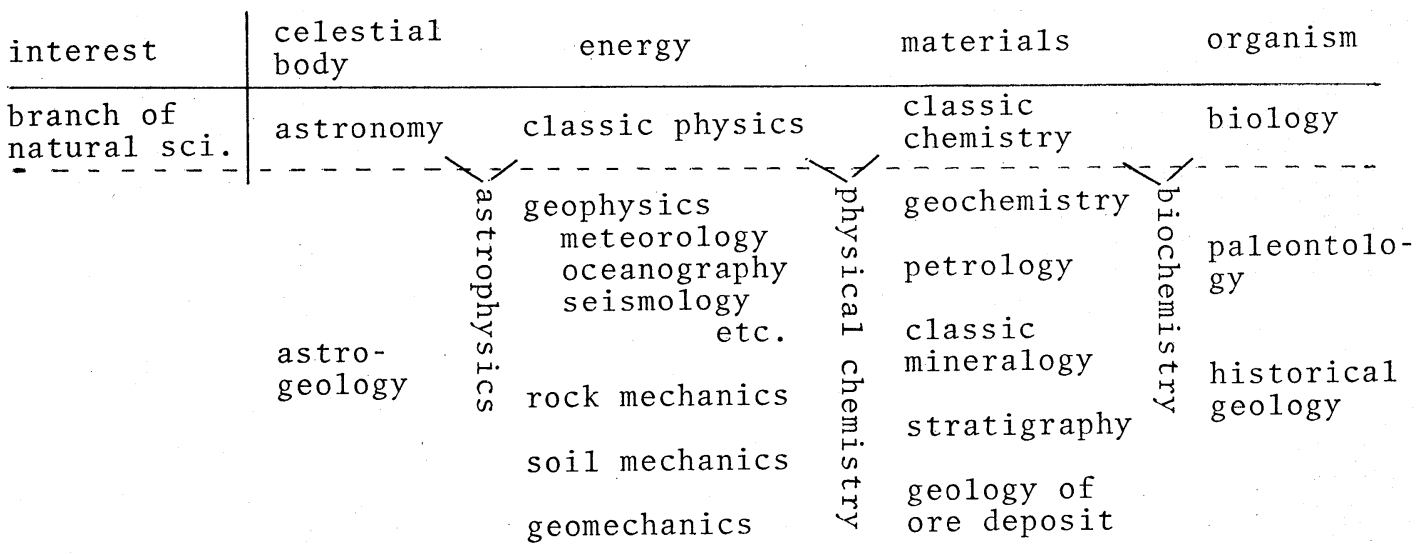

structural geology

\begin{tabular}{l|l}
\begin{tabular}{l|l} 
branch of \\
natural sci.
\end{tabular} & geology \\
\hline interest & earth crust
\end{tabular}

3. Geology in relation to practical works.

Geology in the way of material science has had great contribution to mining industry through oil-, coal- and ore deposit geology 


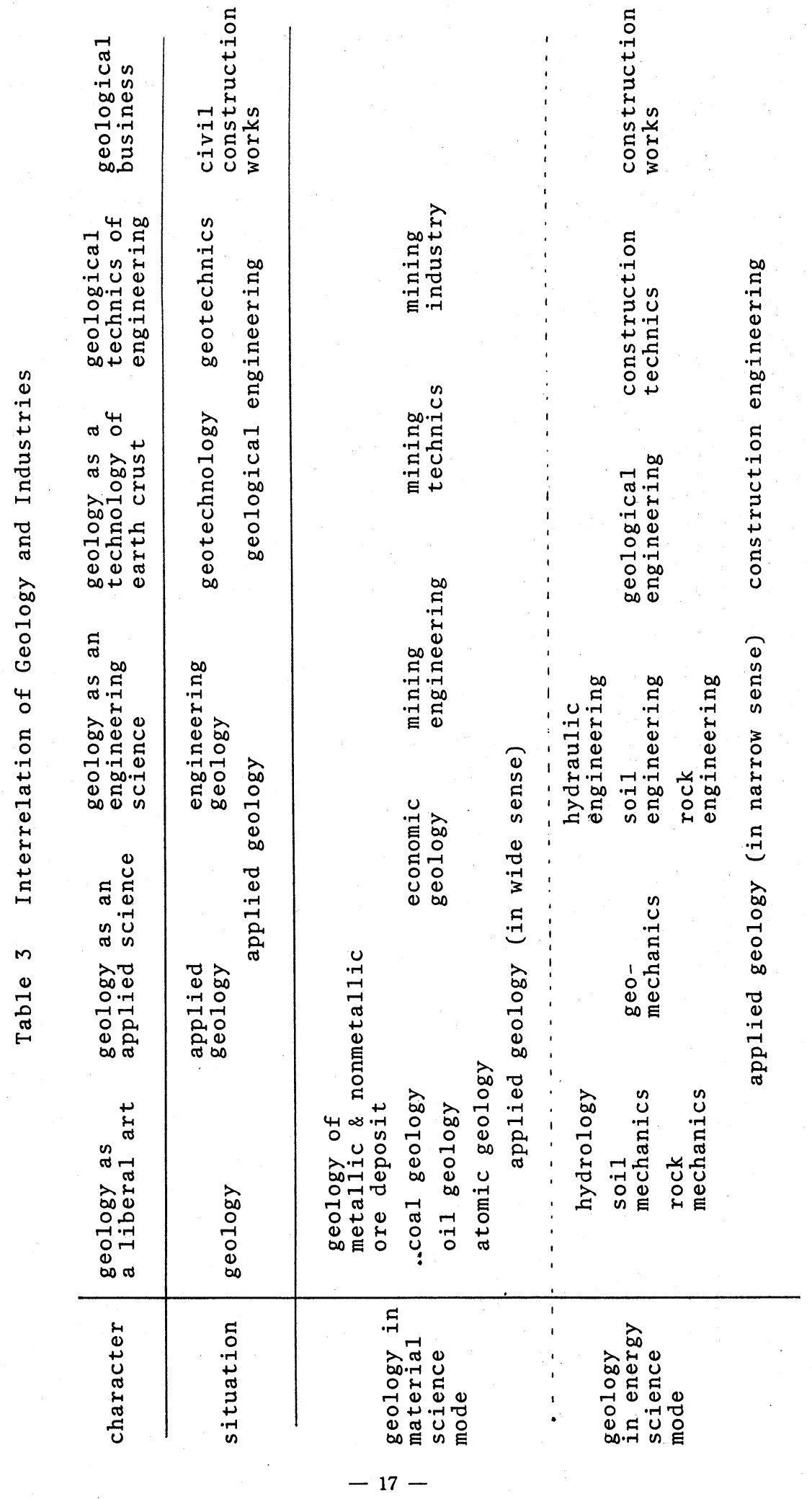


that are grouped into economic geology which had been called applied geology in the beginning.

This series lies as a continuous field of engineering in wide sense covering geological field from academic geology, applied and engineering sciences, technology, engineering in narrow sense, technics to mining industry, and has had much distinguished contributions as science and technology.

On the other hand geology in the way of energy science lies as a basis for applied geology, engineering geology, geotechnology, geological engineering and construction works as shown in Table 3 .

The latter series is also a continuous field which is to relate geology to construction works on/in the earth crust as the engineering of the earth crust i.e. geological engineering.

The situation of these series is comparable to that of engineering chemistry linking academic chemistry and chemical industries, resolving and synthetic.

The field which is covered by the both series is engineering geology in wide sense. The former field is concerned mainly with materials to be extracted from the earth's crust. The latter field is concerned mainly with physicomechanical properties of the earth's crust and in most cases it is related to civil construction works. The latter field is engineering geology in narrow sense or in modern sense. The field is to be, or rather should be taken up for research purpose as well as for practical purposes. Problems in the field of engineering geology stimulate the development of academic geology and vise versa.

4. General view on the character of civil construction works.

Various civil construction works place their ultimate aim in common at the promotion of civilization on the earth. Main purposes of civil construction works can be classified into the following four items:(1) Improvement of living circumstances which includes regional, urban planning and development, reclamation, water works, sewerages etc.

(2) Transportation on or in the lithosphere, hydrosphere and atmosphere

which includes highway-, railway traffic, navigation and aviation.

(3) Utilization of the energy of the earth including flow, wave of water and air, tide, fuel, subterranean heat etc.

(4) Managing the energy of the earth including wave, stream, littoral current, gravity, wind, seismicity, volcanism etc.

For these general purposes some main structures built are common.

Most elementary works for building various structures are often common such as excavation, banking, erection, concreting etc. Fundamental engineering or technology is more common than elementary works.

5. An assist in attempting to select materials in teaching and training of engineering geology.

An example of standard major course is shown in Table 4. Most of the subject in the table introduce those adopted by the Department of Foundation engineering in direct translation, the Department of Geotechnology in its idea or the Department of Civil and Geological Engineering in its explanatory meaning, of School of Science and Engineering, Saitama University. The table contains minor personal amendment by the author.

Almost all fundamental subjects of engineering or technology supporting the elementary works for main structures of civil construction are contained in the table.

Since modern engineering geology has geology in energy science approach at its basis, it naturally has to follow physicomechanical mode of approach to geology. 
Table 4 Standard Major Course

\begin{tabular}{|c|c|c|c|}
\hline GRADE & TERM & ANNUAL SUBJECT & SEMI - ANNUAL SUBJECT \\
\hline \multirow{2}{*}{$\begin{array}{l}\text { FIRST } \\
\text { YEAR }\end{array}$} & 1st Term & \multirow{2}{*}{$\begin{array}{l}\text { * Basic Concept on } \\
\text { Geotechnology (4) } \\
\text { Exercise on Genera1 } \\
\text { Geotechnology (4) } \\
\text { * Stratigraphy (4) }\end{array}$} & Engineering Mathematics I (2) \\
\hline & 2nd Term & & $\begin{array}{l}\text { Engineering Mathematics II (2) } \\
\text { *Drawing (1) }\end{array}$ \\
\hline \multirow[t]{2}{*}{$\begin{array}{l}\text { SECOND } \\
\text { YEAR }\end{array}$} & 1st Term & \multirow{4}{*}{$\begin{array}{l}\text { Structural Geology (4) } \\
\text { *Stratigraphy, Exercise } \\
\text { (2) } \\
\text { *Soil Engineering I (4) } \\
\text { *Hydraulics I (4) } \\
\text { *Exercise on Hydraulics } \\
\text { (2) } \\
\text { *Applied Mechanics (4) } \\
\text { *Applied Mathematics, } \\
\text { Exercise (2) } \\
\text { *Surveying (4) } \\
\text { *Surveying, Exercise (2) } \\
\text { - *Rock Engineering I (4)- } \\
\text { Soil Engineering II (4) } \\
\text { *Soil Engrg., Lab. (2) } \\
\text { Engineering Petrology } \\
\text { II (4) } \\
\text { *Concrete Engrg., Lab. } \\
\text { (2) } \\
\text { Geophysica1 Prospecting } \\
\text { * } 4)\end{array}$} & $\begin{array}{l}\text { *Engineering Petrology (4) } \\
\text { Engineering Materials (2) }\end{array}$ \\
\hline & 2nd Term & & $\begin{array}{l}\text { *Engineering Petrology, Lab. (2) } \\
\text { *Concrete Engineering (2) } \\
\text { *Seismology (2) }\end{array}$ \\
\hline \multirow{2}{*}{$\begin{array}{l}\text { THIRD } \\
\text { YEAR }\end{array}$} & 1st Term & & $\begin{array}{l}\text { Site Investigation (2) } \\
\text { *Rock Engineering, Lab. (2) } \\
\text { *Hydraulics, Lab. (2) } \\
\text { *Hydraulics II (2) } \\
\text { Sewerage Engrg. (2) } \\
\text { Reinforced Concrete Engrg. I } \\
\text { (2) } \\
\text { *Bridge Engineering (2) } \\
\text { *Structural Engrg. I (2) } \\
\text { *Structural Engrg.,Lab. (2) }\end{array}$ \\
\hline & 2nd Term & & $\begin{array}{l}\text { Aerial Photogrammetry (2) } \\
\text { *Rock Engineering II (2) } \\
\text { Rock Engineering, Exercise (2) } \\
\text { Hydrodynamics (2) } \\
\text { Hydrology (2) } \\
\text { Reinforced Concrete Engrg. II } \\
\text { (2) } \\
\text { *Geophysical Prospecting, Lab. } \\
\text { (2) } \\
\text { Seismic Engineering II (2) } \\
\text { Structural Engrg. II (2) } \\
\text { Architect Structural Engrg. (2) } \\
\text { *Structure Design Drawing (2) }\end{array}$ \\
\hline \multirow{2}{*}{$\begin{array}{l}\text { FOURTH } \\
\text { YEAR }\end{array}$} & 1st Term & \multirow{2}{*}{$\begin{array}{l}\text { - River \& Coastal Engrg. } \\
\text { (4) } \\
\text { Highway Engrg. ( } 4) \\
\text { GRADUATION THESIS (4) }\end{array}$} & $\begin{array}{l}\text { Erosion Control Engrg. (2) } \\
\text { Ground Water Engrg. (2) }\end{array}$ \\
\hline & 2nd Term & & Explosives Engineering (2) \\
\hline
\end{tabular}

Remarks: 1. Figures in ( ) indicate units of the subject.

2. GRADUATION THESIS is required.

3. Asterics indicates that the cource is designated elective.

4. Students are required to take:-

4 (required) + more than 60 among designated electives. electives $=$ more than 84 units. 